\title{
バフンウ二卵巣脂質について \\ Lipids of the Sea Chestnut Roe
}

(昭 和 42 年 5 月 7 日 受 理)

\author{
皇山繁 金田尚志 \\ (Shigeru Hatakeyama) (Takashi Kaneda)
}

Roe of the sea chestnut is one of favorite relishes among Japanese. Excessive eating of the roe, however, is believed to often cause nasal hemorrhage in which lipids of the roe probably participates as a stimulant. To cast a scientific light on the common belief relevant to the physiological phenomenon, composition of the lipids from mature ovaries of a sea chestnut, Heliecidaris crassispina, has been determined.

The whole lipids were extracted with chloroform/methanol solution. The lipids were fractionated by column chromatography with activated silicic acid and stepwise elution, with increasing concentration of ethyl ether in $n$-hexane. Phospholipid components were separated in the same way but by the use of methanol/chloroform solutions. The components were identified by thin layer chromatography and chemical tests.

The results indicated that the whole lipids contained in the ovaries represented, on the wet weight basis, 9.8 per cent of the sample. Of the whole lipids approximately 70 per cent was phospholipids which. consisted of lecithin ( $51.6 \%)$, cephalin (16.6\%), sphingomyelin (13.6\%), phosphoinositide and lysolecithin (both $9.1 \%$ ). Upon analyzing fatty acids of each fraction by gas-liquid chromatography, it was found that more than one half of mixed fatty acids comprised $\mathrm{C}_{20}$ and $\mathrm{C}_{22}$ acids. In particular, lecithin was characteristically rich in $\mathrm{C}_{22}:{ }_{1}$ acid (47.4\%).

ウニは古くから珍味食品として日本人の食卓をかざっ てきたが，ウニを多量に食べると番血が出るといわれ， これはウニの脂質によるなどとされている。そこで， バ フンウニの卵巣脂質の性状について調べた。

ウ二の脂質については, 最近, 露木, 望月1) らがムラサ キウニについて報告しているが, 脂肪酸組成についての くわしい報告はなされていない。また外山，高木22)らは ハンンウニの脂質の脂肪酸組成について調べているが, 筆者らの得た結果はまったく異なったものであった。

\section{実験方法および結果}

\section{1. 試料}

三陸産ハンンウ (Heliecidaris crassispina) 卵巣

\section{2. 試料より総脂質の抽出}

Olcott $^{3)}$ らが Bligh") らの方法に準拠して行った方法 によった。すなわち,一定量の試料にクロロホルム：メ タノール $(2: 1)$ 混液 3 倍量を加え, 2 分間ブレンダーにか けホモジナイズし，さらに 1 倍量のクロロホルムおよび 水を加えて1分間ホモジナイズをくりかえす。ホモジナ イズしたものをロ過し，組織の残椬を 1 倍量のクロロホ ルムで再び抽出ロ過す。(ホモジナイズの際酸化を妨ぐた
めにハイドロキノンの結晶を加えた。)ロ液のクロロホル. 么增を取り出し, クロロホルムを減王下で除去し, 総脂. 質を得た。得られた総脂質の重量を測定したところ試料 (wet weight)に対する重量\%は9.8\%であった。

3. ケイ酸カラムクロマトによる脂質の分別

総脂質はケイ酸カラムクロマトグラフィーによる分画: を行った。使用したケイ酸は Mallinckrodt No. 2847で これを塩酸処理し,メタノールで 5 回洗ってから $110^{\circ} \mathrm{C}$ で 4 時間活性化した。本ヶイ酸 $8 \sim 10 \mathrm{~g}$ を長さ $35 \mathrm{~cm}$, 直径 $1 \mathrm{~cm}$ のカラムに詰め, メタノール, アセトン, エ. 一テル,ヘキサンを順次 $50 \mathrm{ml}$ ずつ流した後, ヘキサン に溶かした総脂質を加えた。(ケイ酸 $1 \mathrm{~g}$ に対し, 脂質は 約 $10 \mathrm{mg}$ となるようにした。) ついで表 1 に示す溶媒を 流し，各脂質を溶出分別した。またリン脂質に対しても 同様の処理をしたケイ酸を用いカラムクロマトグラフ 一を行った。すなわち Olcott ら ロロホルム・メタノール混合溶媒中のメタノールの割合. を3，12，18，25，33，50，85\% と順に增してゆき，リ ン脂質を溶出分別した。その溶出曲線は図 1 のごとくで その重量\%は表 2 に示すごとくであった。な打図 1 に㧤: いて，25\%区分および33\%区分をレシチンとしたのは， 
表 1 カラムクロマトによるウ二卵巣脂質の分別

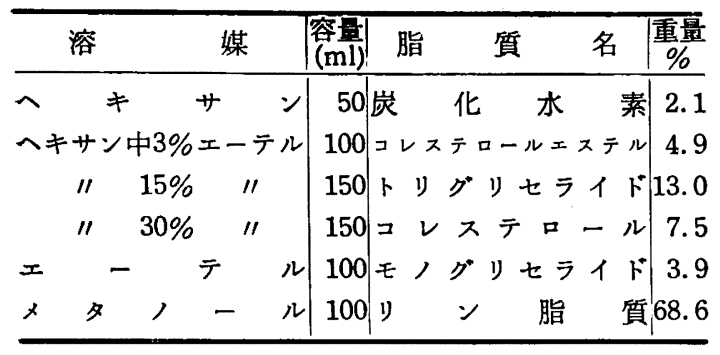

図 1 リン脂質溶出曲線

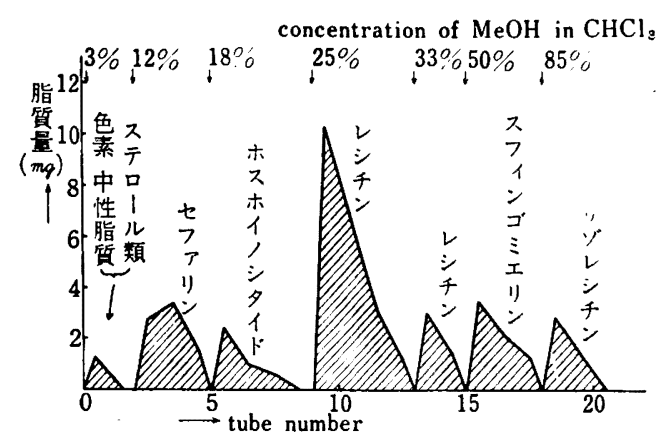

表 2 各リン脂質の重量パーセント

\begin{tabular}{|c|c|c|c|c|c|c|c|c|c|}
\hline & リ & ע & & 脂 & & 質 & \multicolumn{2}{|c|}{ 名 } & 重量\% \\
\hline セ & & & 3 & & リ & ) & & V & 16.6 \\
\hline ホ & ス & ホ & 1 & ノ & シ & タ & 1 & ド & 9.1 \\
\hline$\nu$ & & & , & & f & & & ข & 51.6 \\
\hline ス & $>_{1}$ & & & $\exists$ & $\Sigma$ & $x$ & リ & ン & 13.6 \\
\hline リ & & 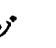 & $v$ & & シ & f & & v & 9.1 \\
\hline
\end{tabular}

薄層クロマトク゚ラフィー(後述)を行なった際その Rf 值 がほは同じ値を示したためで，これは恐らく脂肪酸の差 によると思われるが詳細については不明でなお検討を要 する。

4. 薄層クロマトグラフィーによる脂質の碓認

ケイ酸カラムクロマトグラフィーにより分別した各脂 質を確認するため薄層クロマトグラフィーを行なった。 使用したケイ酸はワコウゲル B-5,プレートは $20 \times 20 \mathrm{~cm}$ のものである。

（1）中性脂質およびステロール類

中性脂質, ステロール類に対しては展開溶媒として, 石油エーテル・エーテル・酢酸 $(90: 10: 1)$ 混液を用い た。発色俞は重クロム酸・硫酸混液を使用した。このと きの Rf 值は表 3 に示す通りである。(展開温度 $10^{\circ} \mathrm{C}$ )。 (2) リン脂質

クロロホルム・メタノール・隶 $(80: 25: 3)$ の混合溶 媒を用いて展開し, 発色剂としては,ニンヒドリン試薬, ドラーゲンドルフ試薬を使用した。（展開温度 $10^{\circ} \mathrm{C}$ )こ
表 3 中性脂質およびステロール類の Rf 値

\begin{tabular}{|c|c|}
\hline 脂 & Rf 値 \\
\hline コレステロールエステル区分 & 0.88 \\
\hline トリグリセライトド & 0.58 \\
\hline 天 ぷら 油（トリグリセライド対照品） & 0.57 \\
\hline モノグリセラ & 0.07 \\
\hline 対照標品 & 0.06 \\
\hline ステロール区 分 & 0.34 \\
\hline 対照標品 & 0.31 \\
\hline
\end{tabular}

表 4 各リン脂質の $\mathrm{Rf}$ 值

\begin{tabular}{|c|c|c|c|c|}
\hline リン脂質名 & Rf 值 & 発 & 色 & 郕 \\
\hline $12 \%$ 区 分 & $0.92 \quad 0.16$ & \multirow{5}{*}{\multicolumn{3}{|c|}{$\begin{array}{c}\text { ニンヒドリン発色 } \\
\| \\
\| \\
\text { ドラーゲンドルフ発色 } \\
\|\end{array}$}} \\
\hline セファリン標品 & $0.82 \quad 0.24$ & & & \\
\hline $18 \%$ 区 分 & 0.18 & & & \\
\hline $25 \%$ 区 分 & 0.43 & & & \\
\hline レシチン栖品 & 0.45 & & & \\
\hline $33 \%$ 区 分 & 0.50 & \\
\hline $50 \%$ 区 分 & 0.64 & \\
\hline $85 \%$ 区 分 & 0.14 & \multicolumn{3}{|c|}{$\prime \prime$} \\
\hline リゾレシチン標品 & 0.12 & \multicolumn{3}{|c|}{ "I } \\
\hline
\end{tabular}

* リン脂質の各区分は図 1 に示したもの。

の際の Rf 値は表 4 に示すと拈りである。

5. 脂肪酸組成の検討

脂肪酸はメチルェステルとしたものを，そのままある いはパラジウム黒を用い接触還元後ガスクロマトグラフ ィーを行い, 同定し, 表 5 に示すごとき結果を得た。こ の際に使用したカラムは Chrom. W に D.E.G.S. 5\% を被覆した $1.5 \mathrm{~m}$ のカラムである。また SE-30の 0.75 $\mathrm{m}$ のカラムも用い検討した。

\section{考察}

以上の結果より考察するに，ウ二卵栄脂質中リン脂質 は総脂質の約70\%をしめ，さらにリン脂質を分別した結 果, レシチンがリン脂質全体の約 $50 \%$ 占めていること を認めた。脂肪酸組成は一般動植物油にくらべ極めて特 異的で $\mathrm{C}_{20}$ 以上の脂肪酸が全体の $50 \%$ 以上を占め, この ことについては従来まったく報告されて扰らず，外山 ら²)の報告です触れていない。とくにリン脂質は $\mathrm{C}_{22}: 1$ 酸が半分近くを占めていることは非常に興味深い。また


はウニが海藻を食べ, 海藻脂質が卵巣へ移行したためで はないかと思われる。

総括 バフンウニ卵巣脂質をカラムクロートグラフィーを用 
栄着と食䊓

表 5 各脂質の脂肪酸組成

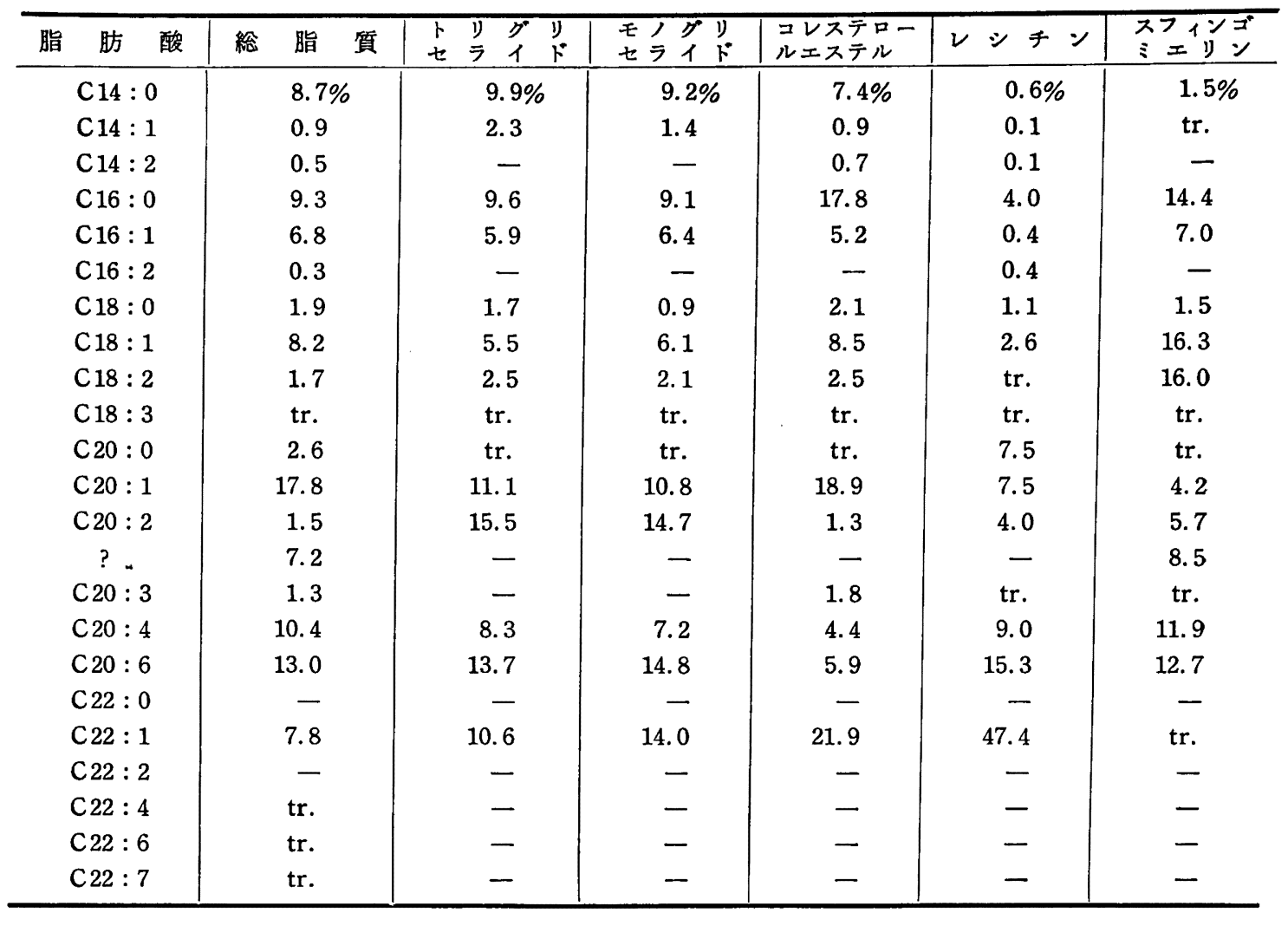

いて分別しつぎの結果を得た。

（1）総栺質は生鮮原料中 $9.8 \%$ であった。脂質中リン 脂質が約70\%を占め,トリグリセライドは13\%程度であ った。リン脂質中 $50 \%$ 程度はレシチンであり，七ファリ ン，スフィンゴミェリンがこれに次いだ。

(2) ハシフンウニ卵巣脂質の脂肪酸は極めて特異的で, 炭素数 20 以上の脂肪酸か $50 \%$ 以上を占め, とくにリン脂 質には $\mathrm{C}_{22}: 1$ 酸が50\%ちかくふくまれていた。

\section{文献}

1）露木, 望月：日本食品工誌, 13，14 (1966)

2) 外山, 高木: 日化誌, 74, 842 (1953)

3) C. Yvonne Shuster, J.R. Froines, and H.S. Olcott : J. Am. Oil Chem. Soc., 41, 36 (1964)

4) Bligh, E. G., and W. J.Dyer : Can. J. Biochem. Physiol., 37, 911 (1959)

5）薄㬝クロマトグラフィー (南山堂) (1960)

(東北大学農学部食糧化学科) 